\title{
Peran Program Kelas Literasi dalam Meningkatkan Kemampuan Literasi Informasi Mahasiswa Universitas Nahdlatul Ulama Yogyakarta
}

\author{
Almer Samantha Hidaya, ${ }^{{ }^{*}}$ Marwiyah $^{2}$ \\ ${ }^{1}$ Konsentrasi Ilmu Perpustakaan dan Informasi Pascasarjana \\ UIN Sunan Kalijaga Yogyakarta \\ ${ }^{2}$ Prodi Ilmu Perpustakaan UIN Sunan Kalijaga Yogyakarta \\ *samanthahidaya@gmail.com
}

\begin{abstract}
The rapid development of information technology makes information spread and open which can be accessed from any where and at any time. The development of information technology must also be balanced with the ability to search and identify information properly and correctly, which is then known as information literacy. But this ability is not yet fully owned by information users, especially students. This makes the ability of information literacy is an urgent matter, especially on scientific information. Departing from the low level of scientific information literacy, students need to receive scientific information literacy training, especially in the early years of lectures. This research uses research and development (R\&D) methods. Literacy class participants used as informants in this study were determined randomly, which came from the first year students of each study program in the academic year 2019/2020. In the initial stage of this study a measurement of the level of knowledge and literacy ability of students of trainees (classes) was carried out using a pretest. In the next stage class material was carried out as well as practice in order to obtain results in the form of applied skills that could be directly applicable. The material includes general knowledge about scientific information, effective search methods and strategies, searching of electronic journal portal both paid and open access, as well as using and evaluating information including citations. At the final stage of this study a posttest was conducted to see the
\end{abstract}


extent of the effectiveness of this training model and class participants' understanding of scientific information literacy after attending literacy classes. The results of this program show an increase in students' information literacy skills.

Keywords: Information literacy, scientific information

\begin{abstract}
Abstrak
Perkembangan teknologi informasi yang semakin pesat menjadikan tersebar dan terbukanya infomasi yang dapat diakses dari manapun dan kapanpun juga. Perkembangan teknologi informasi tersebut juga harus diimbangi dengan kemampuan menelusuri dan mengidentifikasi informasi secara baik dan benar yang kemudian dikenal dengan istilah literasi informasi (information literacy). Namun kemampuan tersebut belum dimiliki secara penuh oleh pengguna informasi, terutama mahasiswa. Hal tersebut menjadikan kemampuan literasi informasi merupakan suatu hal yang urgent terutama pada informasi ilmiah. Berangkat dari rendahnya tingkat literasi informasi ilmiah tersebut, maka mahasiswa perlu mendapatkan pelatihan literasi informasi ilmiah terutama pada tahun awal perkuliahan. Penelitian ini menggunakan metode research and develpment $(R \& D)$. Peserta kelas literasi yang digunakan sebagai informan dalam penelitian ini ditentukan secara acak (random sampling), yang berasal dari mahasiswa tahun pertama setiap program studipada tahun akademik 2019/2020. Pada tahap awal penelitian ini dilaksanakan pengukuran tingkat pengetahuan dan kemampuan literasi mahasiswa peserta pelatihan (kelas) dengan menggunakan pretest, Pada tahap berikutnya dilaksanakan materi kelas sekaligus praktik guna mendapatkan hasil berupa keterampilan terapan yang bisa secara langsung bersifat aplikatif. Materi meliputi pengetahuan umum mengenai informasi ilmiah, cara dan strategi penelusuran efektif, penelusuran portal jurnal eletronok baik yang berbayar maupun open access, serta menggunakan dan mengevaluasi informasi termasuk didalamnya sitasi. Pada tahap akhir dari penelitian ini dilaksanakan posttest guna melihat sejauh mana efektivitas model pelatihan ini dan pemahaman peserta kelas terhadap literasi informasi ilmiah setelah mengikuti kelas literasi. Hasil dari program ini menunjukkan adanya peningkatan kemampuan literasi informasi mahasiswa.
\end{abstract}

Kata kunci: literasi informasi, informasi ilmiah 


\section{Latar Belakang}

Perkembangan dunia teknologi informasi yang semakin masif menjadikan terbukanya infomasi yang dapat diakses dari manapun dan kapanpun juga. Hal ini mengakibatkan terjadinya fenomena ledakan informasi (information explotion). Ledakan informasi ditandai dengan sulitnya mencari informasi yang tepat, sulitnya memilih informasi yang dibutuhkan dan sulitnya mendapatkan informasi yang sesuai dikarenakan informasi yang datang setiap detiknya sangat banyak dan tidak terbendung (Khadijah, et al. 2016). Selain ledakan informasi, menurut Richard E. Rubin terdapat tiga fenomena lainnya, yaitu fload of information (banjir informasi), bombarded by information (pengeboman oleh informasi), dan information overload (kelebihan/ terlampau banyak informasi) (Rubin 2004). Fenomena diatas menunjukkan bahwa pesatnya perkembangan teknologi informasi bagaikan dua sisi mata pisau, dimana merupakan peluang yang memberikan kemudahan dalam akses informasi, namun disisi lain merupakan ancaman bagi yang belum siap dan tidak memiliki kemampuan literasi informasi.

Dari fenomena diatas, kemampuan menelusuri dan mengidentifikasi informasi secara baik dan benar yang kemudian dikenal dengan istilah literasi informasi (information literacy) menjadi suatu hal yang harus benarbenar dimiliki dan dikuasai. Literasi informasi adalah kemampuan mencari, mengevaluasi dan menggunakan informasi yang dibutuhkan secara efektif (Hasugian 2008). Tujuan dari literasi informasi ini adalah memudahkan seseorang untuk belajar secara mandiri, memilah informasi yang akan digunakan ditengah era ledakan informasi, serta memenuhi kebutuhan informasinya baik untuk kebutuhan bersosialisasi, mencari pekerjaan, mencari informasi mengenai kesehatan ataupun informasi mengenai kehidupan dalam lingkungan bermasyarakat (Khadijah, et al. 2016).

Namun demikian, kemampuan tersebut belum dimiliki secara penuh oleh sebagian besar pengguna informasi, terutama mahasiswa. Seperti halnya pada mahasiswa Universitas Nahdlatul Ulama (UNU) Yogyakarta. Hal ini diketahui berdasarkan hasil penilaian awal dari 30 peserta kelas 
literasi dengan nilai rata-rata 23 dalam pengetahuan dan kemampuan literasi informasi. Padahal kemampuan memahami dan menelusuri informasi merupakan modal awal bagi mahasiswa dalam melaksanakan tugasnya sebagai seorang akademisi. Penguasaan literasi informasi bagi mahasiswa tidak hanya bertujuan untuk menjadikan mahasiswa sebagai individu yang literat, yang mampu menyelesaikan tugas-tugas akademisnya dengan baik, tetapi juga karena merekalah nantinya yang akan menularkan dan mengajarkan kompetensi ini ke masyarakat dan lingkungan kerjanya.

Melihat rendahnya tingkat literasi informasi ilmiah tersebut, maka mahasiswa perlu mendapatkan pelatihan literasi informasi ilmiah terutama pada tahun awal perkuliahan. Pelatiahan berupa kelas literasi diharapkan mampu memberikan ketrampilan literasi yang sekaligus bersifat terapan atau aplkatif yang dimiliki oleh mahasiswa sejak tahun pertama perkuliahannya. Disamping itu, program kelas literasi sebagai pilot project semacam ini diharapkan dapat diterapkan dan dilaksanakan pada tahun-tahun berikutnya. Berangkat dari latar belakang diatas, penelitian ini bertujuan untuk mengetahui "bagaimana peran program kelas literasi dalam meningkatkan kemampuan literasi informasi mahasiswa?”

\section{Tinjauan}

\section{a. Tinjauan Pustaka}

Ada beberapa penelitian terdahulu relevan yang telah dilakukan oleh peneliti sebelumnya yang bersesuaian dengan penelitian ini, penelitian tersebut diantaranya yaitu:

Pertama, penelitian yang dilakukan oleh Husain Haikal Prama, dengan judul Class Library sebagai Program Literasi Informasi di Perpustakan SD Islam Al-Azhar 20 Cibubur. Penelitian ini bertujuan untuk mengetahui tentang pelaksanaan clas library dalam meningkatkan literasi informasi siswa. Jenis pendekatan dalam penelitian ini adalah deskriptif dengan jenis penelitian kualitatif. Hasil dari penelitian menunjukkan bahwa dalam kegiatan ini siswa diajarkan bagaimana menelususri informasi dengan baik 
dan benar serta relevan sesuai dengan kebuthannya. Dari hasil penelitian ini pula diketahui clas library dapat memotivasi siswa untuk tidak hanya datang dan berdiam diri saja di perpustakaan tetapi untuk mencari segala macam sumber informasi yang ada dan menggunakannya dengan tepat guna (Prama 2015).

Kedua, adalah penelitian yang dilakukan oleh Sri Rohyanti Zulaikha, Siti Partini Suardiman, dan Sodiq A. Kuntoro dengan judul Pengembangan Model Perpustakaan Madrasah dalam Penerapan Literasi Informasi untuk Mempersiapkan Belajar Sepanjang Hayat. Tujuan penelitian ini untuk mengetahui pengembangan model perpustakaan madrasah dalam penerapan literasi informasi untuk mempersiapkan belajar sepanjang hayat dan mengetahui kemampuan belajar sepanjang hayat bagi para pemustaka. Metode penelitian ini adalah R\&D dengan pendekatan kualitatif. Hasil penelitian pengembangan model perpustakaan madrasah ini terlihat dalam enam tahap (Task Definiton, Information Seeking, Location and access, Use of Information, Syntesis dan Evaluation) yang diimplementasi di dalam RPP untuk bidang studi terkait (Bahasa Indonesia, Biologi, Fiqih dan PPMB) dengan pengembangan layanan perpustakaan yang berbasis kepada pemustaka. Model perpustakaan yang "literate" terhadap informasi dapat menjadikan siswa menyenangi belajar, mengetahui bagaimana sejatinya cara belajar itu, menghargai bahwa belajar itu, rasa ingin tahu terhadap sesuatu menjadikan sikap "self directing" dalam belajar (Zulaikha, Suardiman dan Kuntoro 2015).

\section{b. Tinjauan Teori}

1) Literasi informasi

Pengertian literasi informasi secara umum adalah kemelekan informasi, yang artinya melek terhadap informasi. Menurut Dictionary for Library and Information Science mendefinisikan literasi informasi:

"Information literacy is skill in finding the information one needs, including and understanding of how libraries are organized, fami- liarity with resource they provide (including information formats and automated search tools), and 
knowledge of commonly used techniques. The concept also includes the skills required to critically evaluate information content and employ it effectively, as well as understanding of the technological infrastructure on which information transmission is based, including its social, political, and cultural context and impact (Eisenberg 2004).”

Berdasarkan definisi tersebut maka literasi informasi adalah kemampuan mencari informasi yang dibutuhkan, termasuk dalam memahami bagaimana cara mengelola perpustakaan, mengetahui istilah sumber daya yang di produksi termasuk format informasi dan alat pencarian informasi yang terautomasi serta mengetahui teknik-teknik yang biasa digunakan dalam pencarian informasi. Konsep tersebut juga termasuk dalam kemampuan mengevaluasi isi informasi dan menggunakannya secara efektif.

Sejalan dengan definisi diatas, America Library Association (ALA) mendefinisikan literasi infoemasi adalah:

"is a set of abilities requiring individuals to recognize when information is needed and have the ability to locate, evaluate, and use effectivelly the needed information (Association t.thn.)."

Maksudnya adalah literasi informasi merupakan kemampuan individu dalam menentukan kapan informasi dibutuhkan dan mempunyai keahlian untuk menemukan, mengevaluasi dan menggunakannya secara efektif sesuai dengan kebutuhannya.

\section{2) The Big Six Model}

The Big Six Model adalah suatu model literasi informasi yang dikembangkan oleh Mike Eisenberg dan Bob Berkowitz. Model ini merupakan literasi informasi dengan pendekatan sistematis untuk menyelesaikan permasalahan informasi yang bergantung pada keterampilan pemikiran kritis. The Big Six Model memilki beberapa tahapan, yaitu (Zulaikha 2008):

a) Definisi tugas

Meliputi pendefinisian masalah dan mengidentifikani masalah-masalah (kebutuhan informasi) yang ada. 
b) Strategi pencarian informasi

Strategi pencaian informasi itu meliputi pembuatan keputusan dengan memperhatikan sumber-sumber informasi yang diharapkan dapat sesuai dengan tugas yang telah dikerjakan Menentukan sumber-sumber yang memungkinkan bisa digunakan dengan cara mendaftar dimana informasi tersebut dapat ditemukan dan menginventarisir sumber-sumber, kemudian mengevaluasi sumber-sumber yang berbeda dan memutuskan apakah memang akan digunakan atau tidak, apakah harus menanyakan permasalahan kepada ahlinya atau tidak. Kemudian Harus dicari strategi apa yang memungkinkan untuk memecahkan sebuah masalah.

c) Lokasi dan akes informasi

Lokasi sumber-sumber informasi baik dari segi subjeknya maupun fisiknya. Menemukan informasi dengan sumber yang lengkap. Lokasi dan akses merupakan implementasi dari strategi pencarian informasi.

d) Penggunaan informasi

Penggunaan informasi ini antara lain meliputi pembuatan catatan bibliografi dari sumber-sumber yang ada termasuk mencatat artikel yang ada dalam sebuah majalah atau jurnal

e) Sintesis

Mengorganisir sumber-sumber informasi yang ada dengan membuat catatan yang berururtan secara logika dan mencetak hasil laporan

f) Evaluasi

Langkah evaluasi meliputi keputusan produk apa yang dihasilkan dari sebuah pelaporan, misalnya, hasilnya adalah sebuah makalah, artikel ataupun produk informasi lainnya.

\section{Metode}

Dalam penerapan model pelatihan literasi ini digunakan metode penelitian dan pengembangan atau research \& develpment (R\&D). Metode penelitian $\mathrm{R} \& \mathrm{D}$ digunakan untuk menghasilkan produk tertentu, dan menguji kefektifan produk tersebut. Untuk dapat menghasilkan produk 
tertentu digunakan penelitian yang bersifat analisis kebutuhan (digunakan metode survey atau kualitatif) dan untuk menguji kefefektifan produk tersebut supaya dapat berfungsi di masyarakat luas, maka diperlukan penelitian untuk menguji kefektifan produk tersebut (Sugiyono 2015). Dalam penelitian ini diharapkan kedepannya metode pelatihan literasi informasi ini dapat diterapkan pada tahun berikutnya.

Metode R\&D memiliki beberapa tahapan dalam pelaksanaannya sehingga dalam pelaksanaannya dapat berjalan dengan maksimal sesuai dengan prosedur penelitian. Penelitian R\&D diawali dengan 1) menentukan potensi dan masalah, 2) pengumpulan informasi, 3) desain sekaligus validasi produk, 4) dilakukan uji coba dan pemakaian. Selanjutnya apabila produk dirasa sudah efrktif dan layak serta tidak memerlukan revisi yang berarti, kemudian 5) produk dapat diproduksi masal, dalam artian model pengembangan dapat diterapkan pada periode berikutnya. Hasil akhir dari penelitian ini adalah sebuah produk berupa panduan kelas literasi informasi bagi mahasiswa.

\section{Hasil Dan Pembahasan}

Dewasa ini, perkembangan teknologi informasi yang semakin pesat merupakan potensi bagi dunia ilmu pengetahuan. Kebutuhan informasi bagi akademisi dapat dengan mudah termpenuhi dengan adanya keberlimpahan informasi di berbagai media terutama di media digtal dengan jaringan internet. Keberlimpahan informasi memungkinkan seseorang untuk memperoleh informasi yang dia butuhkan dalam waktu yang singkat, dimanapun dan kapanpun juga. Namun disamping itu hal tersebut juga menjadi suatu masalah dikareakan tingkat literasi sebagian besar masyarakat (termasuk masyarakat akademik) masih rendah, sehingga sangat rawan terjadinya misinformasi, disinformasi, dan malinformasi, atau mendapatkan informasi yang sebenarnya tidak dibutuhkan.

Dari permasalahan yang disertai dengan potensi diatas, perlu dilakukan suatu upaya untuk mengatasinya, salah satunya melalui program pelatihan literasi. Sebelum dilaksanakan penyusunan program literasi perlu 
adanya pengumpulan informasi dan penilaian pada tingkat pengetahuan dan kemampuan literasi informasi mahasiwa. Selain untuk mengukur kemampuan hal ini juga bertujuan untuk mengetahui bagian dan tahapan mana yang perlu mendapatkan perhatian dan porsi lebih dalam materi pelatihan.

\section{a. Pengumpulan informasi}

Pada tahap ini dilakukan penilaian terhadap mahasiswa UNU Yogyakarta peserta pelatihan (kelas) yang bejumlah 30 (tiga puluh) orang dengan menggunakan pretest. Pretest digunakan untuk mengukur kemampuan peserta mengenai pengetahuan dan kemampuan literasi meliputi informasi ilmiah dan akademis, informasi valid dan hoax, strategi penelusuran informasi, akses jurnal elektronik, evaluasi dan penggunaan informasi. Pretest dilakukan dengan cara pengerjaan soal sebanyak 20 (dua puluh) butir soal, yang dihitung dengan rumus sebagai berikut:

$$
\mathrm{N}=\mathrm{B} \times 5
$$

$\mathrm{N}=$ Nilai

$\mathrm{B}=$ Benar

Dari hasil pretest, dikoreksi dengan bobot nilai pada setiap jawaban yang benar adalah 5 (lima) kemudian dihitung nilai rata-ratanya dan diketahui nilai rata-rata tingkat pengetahuan dan kemampuan literasi peserta kelas literasi sebesar 23. Hal ini menunjukkan rendahnya tingkat literasi informasi mahasiswa. Selain itu hasil pretest juga menunjukkan mahasiswa belum mampu menentukan sumber-sumber informasi yang relevan dan sesuai untuk digunakan sebagai sumber informasi ilmiah.

\section{b. Desain dan validasi produk}

Berdasarkan hasil penilaian awal tersebut kemudian disusun rancangan program pelatihan literasi informasi yang sesuai dengan kebutuhan. Rancangan program selanjutnya divalidasi. Validasi rancangan program dilaksanakan melalui diskusi dengan kepala perpustakaan dan 
pustakawan sebagai leading sector program kelas literasi. Dari hasil akhir penrencanaan dan penyusunan program ditentukan model pelatihan dengan model kelas dan presentasi materi. Materi meliputi meliputi informasi ilmiah dan akademis, informasi valid dan hoax, strategi penelusuran informasi, akses jurnal elektronik. Pelaksanaan materi diprogram selama dua pertemuan dengan durasi setiap pertemuan selama 3 (tiga) JPL atau 150 menit.

\section{c. Uji coba dan pemakaian produk (pelaksanaan kelas literasi)}

Berdasarkan rancangan program yang telah disusun, kemudian program diujicoba penerapan atau pemakaiannya. Pada pelaksanan program kelas literasi ini dilaksanakan materi kelas sekaligus praktik guna mendapatkan hasil berupa keterampilan terapan yang bisa secara langsung bersifat aplikatif. Hal ini dilakukan karena literasi informasi merupakan kemampuan soft skill yang tidak hanya dituntut untuk memiliki pengetahuan saja, akan tetapi juga dituntut untuk memiliki kemampuan analisis dan keterampilan penerapannya saat menemui suatu kebutuhan informasi.

Selanjutnya materi kelas yang diberikan meliputi pengetahuan umum mengenai informasi ilmiah. Informasi ilmiah perlu mendapatkan perhatian lebih dalam model pelatihan semacam ini, dikarenakan jenis informasi bagi akademisi adalah informasi ilmiah. Selain itu informasi ilmiah memiliki syarat dan ciri khas tersendiri yang menjadikannya memiliki nilai dan tingkat kevalidan lebih dibanding dengan jenis informasi lainnya, seperti didasarkan pada fakta (empiris), memiliki penanggung jawab yang jelas, melalui metodologi ilmiah, memiliki rujukan yang jelas, dan teruji secara teoritis. Sehingga penelusuran informasi ilmiah memiliki strategi dan cara yang sedikit banyak berbeda dengan penelusuran informasi pada umumnya.

Selanjutnya setelah mahasiswa mampu mendefinisikan dan mengidentifikasi kebutuhan informasinya, kemudian peserta harus mampu menetapkan semua sumber-sumber yang memungkinkan untuk digunakan. Mahasiswa dalam kaitannya sebagai sorang akademisi perlu mengetahui sumber-sumber informasi ilmiah sebagai bahan referensinya. Salah satu sumber informasi ilmiah yang dapat diakses oleh mahasiswa adalah portal 
jurnal eletronok baik yang berbayar maupun yang tidak berbayar atau open access. Sebagai seorang akademsi, mahasiswa sangat dimudahkan dengan keberadaan portal jurnal elektronik, yang menyajikan beragam artikelartikel ilmiah yang dapat diakses dari manapun dan kapanpun, sehingga pemanfaatannya pun harus secara maksimal.

Perpustakaan UNU Yogyakarta telah melanggan dua basis data jural elektronik yaitu Ebsco dan ProQuest, sehingga mahasiswa UNU Yogyakarta diharapka dapat memanfaatkannya secara maksimal sebagai sumber referensi informasi ilmiah. Selain dua basis data jurnal elektronik yang dilanggan oleh UNU Yogyakarta diatas, mahasiswa juga perlu mengetahui portalportal dan/ atau basis data jurnal elektronik yang bersifat open access seperti Perpustakaan Nasional Republik Indonesia (Perpusnas), Portal Garuda Indonesian Publicationi Index (IPI), Lembaga Ilmu Pengetahuan Indonesia (LIPI), International Organization of Scientific Research (IOSR), Directory of Open Access Journals (DOAJ), ResearchGate, Citeseer, Jurnal Cambridge University, Jurnal Oxford University, dan Google Scholar. Namun sayangnya sebagian besar mahasiswa belum mengetahui dan akses dan pemanfaatan basis data jurnal elektronil semacam itu. Padahal pemanfaatan portal dan/ atau basis data jurnal elektronik berbasis open access semacam ini sanagat perlu dipahami oleh mahasiswa, karena dengan portal berbasis open access mahasiswa bisa mendapatkan sumber referensi yang lebih beragam serta akses terhadap sumber informasi yang lebih luas.

Disisi lain, dalam praktiknya pemanfaatan dan akses terhadap beberapa portal dan/ atau basis data jurnal elektronik berbasis open access mengalami beberapa kendala. Kendala yang dihadapi berupa rumit dan sulitnya melakukan pendaftaran pada portal jurnal elektronik. Hal ini dikarenakan beberapa portal mengharuskan pendaftaran keanggotaan terlebih dahulu sebelum dapat mengakses artikel didalamnya. Sementara itu dalam proses pendaftaran beberapa portal mengharuskan menggunakan surat elektronik (surel)/ e-mail institusi perguruan tinggi yang bersangkutan, sedangkan email UNU Yogyakarta sendiri belum terverivikasi di beberapa portal jurnal elektronik tersebut. Hal ini menjadikan beberapa mahasiswa 
peserta kelas literasi tidak dapat melakukan registrasi dan tidak dapat mengakses artikel yang terdapat didalamnya.

Selain itu, dalam pelaksanaannya beberapa portal dan/ atau basis data jurnal elektronik berbasis open access tidak dapat diakses karena dalam proses perbaikan. Dari beberapa kendala diatas kemudian dilakukan beberapa langkah untuk mengatasi kendala tersebut, yaitu dengan cara mengakses portal jurnal elektronik yang lain serta lebih fokus pada pemanfaatan fitur-fitur pencarian yang disediakan pada setiap portal. Disamping itu pemanfaatan portal dan/ atau basis data jurnal elektronik juga sampai pada melakukan pengunduhan artikel yang berisikan informasi yang relefan atau dibutuhkan.

Materi berikutnya setelah menemukan sumber-sumber informasi yang akan digunakan, sehingga peserta harus mampu menentukan dan menggunakan strategi penelusuran informasi. Strategi penelusuran informasi diperlukan agar pencarian yang dilakukan lebih efektif dan efisien. Secara singkat strategi penelusuran informasi bertujuan untuk mempersempit ligkup pencarian, memperoleh informasi yang relevan, menghemat waktu pencaran, dan untuk mempermudah pencarian (Purwono 2008). Strategi pertama yang dilakukan dalam penelusuran informasi adalah penentuan kata kunci (keyword). Kata kunci menjadi hal dasar yang harus diperhatikan karena kesalahan dalam penulisan kata kunci walaupun hanya satu huruf dapat menyebabkan hasil pencarian yang berbeda dari apa yang kita inginkan. Menentukan kata kunci yang tepat dapat dilakukan dengan mencari dalam kamus, ensiklopedi, ataupun thesaurus sesuai dengan kebutuhan informasi. Dalam tahap ini peserta belajar untuk menguasai berbagai istilah beserta padanan kata-nya yang dapat digunakan sebagai kata kunci dalam penelusuran. Selain itu mahasiswa diajarkan juga kemampuan merangkai kata sehingga menjadi suatu frasa yang memiliki makna lain yang dapat digunakan sebagai kata kunci dalam pencarian suatu informasi.

Setelah menentukan kata kunci, strategi berikutnya yaitu peserta belajar mengenai penggunaan fasilitas-fasilitas pencarian. Fasilitas pencarian informasi ada berbagai jenis diantaranya seperti logika boolean yaitu and yang fungsi menampilkan hasil yang mengandung dua atau semua kata tersebut, 
or yang fungsi menampilakan hasil pencarian yang hanya mengandung salah satu dari kata pencarian tersebut, not yang fungsi menampilakan hasil pencarian yang mengandung hanya salah satu kata dan memberikan pengecualian pada kata tertentu, dan near yang fungsi menampilakan hasil pencarian yang mengandung dua kata tersebut namun dalam posisi yang berdekatan. Selain itu, sama halnya dengan logika boolean terdapat pula strategi penelusuran informasi dengan menggunakan karakter matematika yaitu +, -, , dan "” yang memiliki fungsi serupa dengan logika boolean.

Selain strategi penelusuran informasi menggunakan kata dan karakter, penelusuran informasi juga dapat dengan menentukan jenis informasi berdasarkan tipe filenya. Strategi ini bertujuan untuk menspesifikkan pencarian berdasarkan jenis informasi yang akan dicari, sehingga hasil pencarian yang didapat hanya berupa file yang diinginkan. Beberapa tipe file yang dapat dipergunakan dalam pencarian informasi adalah jenis teks yaitu .doc, .txt, .rtf, .pdf, jenis gambar yaitu .bmp, .tif, .gif, .jpg, jenis animasi yaitu .ani, .fli, .flc, jenis video yaitu .avi, . mov, .mpg, .qt, sedangkan untuk jenis audio yaitu .wav, .mid, .snd, .aud, dan untuk jenis web yaitu .htm, .html, .xml, .dhtml, .php untuk jenis file program adalah .exe, .com. Pada tahap ini peserta kelas mempraktikkan penelusuran informasi dengan menkombinasikan beberapa fasilitas pencarian dan tipe informasi yang dicari. Dalam pelaksanaannya diketahui peserta kelas baru mengetahui penggunaan fasilitas pencarian semacam ini dan merasa sangat terbantu dengan memanfaatkan fasilitas pencarian dalam penelusuran informasi.

Disamping strategi-strategi dan fasilitas penelusuran informasi diatas yang bersifat penelusuran dasar (basic search), terdapat pula fasilitas peelusuran yang bersifat lanjutan atau lebih kompleks. Fasilitas ini disebut advanced search atau pencarian lanjutan. Advanced search merupakan fasilitas pencarian yang memberikan ruas-ruas pencarian berdasarkan sudut pandang pencariannya (subjek, penulis, tahun, jenis file, dan ruas pencarian lainnya) sehingga fasilitas ini memberikan hasil yang sangat spesifik bahkan dapat memberikan hasil akhir dalam jumlah yang relatif sedikit. Advanced search dipandang sangat membantu dan dapat mengefektif serta efisienkan pencarian informasi. 
Setelah melakukan pencarian informasi dan memperoleh informasi yang dibutuhkan, tahap berikutnya dalam ketrampilan literasi informasi adalah melakukan evaluasi terhadap informasi yang diperoleh. Hal ini dikarenakan belum tentu informasi yang kita temukan sesuai dengan kebutuhan kita. Selain itu mungkin saja terjadiya misinformasi, disinformasi, dan/ atau mal-informasi tanpa yang kita sadari. Kemungkinan lain adalah adanya data yang sudah tidak relevan atau sudah tidak up to date sehingga informasinya tidak memiliki nilai lagi.

Evaluasi informasi pada program kelas literasi ini lebih menekankan pada informasi digital yang berasal dari internet. Hal ini dikarenakan informasi yang berasal dari internet yang begitu luas dari semua cakupan bidang kehidupan yang terbuka, dibuat oleh siapa saja, setiap orang, dan berbagai lapisan masyarakat atau lembaga dengan mudah. Sehingga kelayakan informasi yang didapat harus dapat ketahui dengan jelas dan dapat dipertanggungjawabkan.

Aspek-aspek evaluasi informasi yang perlu diperhatikan adalah 1) pengarang sebangai penanggung jawab dan afiliasinya dengan suatu organisasi, 2) ketepatan dan kevalidan data dan informasi yang dikandungnya, 3) kebaharuan dan tingkat relevansinya (kekinian), 4) tingkat obyektifitas baik penulis, organisasi, maupun kandungan informasi didalamnya, serta 5) cakupan sumber informasi yang digunakan, baik dalam kandungan informasinya maupun pengelolaannya. Dari hasil evaluasi tersebut mahasiswa dapat menentukan dan memastikan informasi yang akan digunakannya benar-benar tepat dan sesuai dengan kebuthannya. Dalam pelaksanaan pada taham ini, peserta kelas diajarkan untuk mengevaluasi informasi yang telah diperoleh pada tahap sebelumnya. Hasil dari evaluasi tersub kemudian digunakan sebagai pertimbangan dalam menentukan langkah selanjutnya, akankah informasi tersebut digunakan atau mencari informasi yang lainnya.

Setelah informasi dievaluasi, kemudian informasi dapat dipergunakan. Namun penggunaan informasi ilmiah sedikit banyak tidaklah sama dengan informasi pada umumnya. Dalam penggunaan informasi ilmiah memiliki etika yang salah satunya mengenai plagiat. 
"Plagiat adalah perbuatan secara sengaja atau tidak sengaja dalam amemperolehatau mencoba memperoleh kredit ataunilai untuk suatu karya ilmiah, dengan mengutip sebagian atau seluruh karyadan/atau karya ilmiah pihak lain yang diakui sebagai karya ilmiahnya, tanpa menyatakan sumber secara tepat dan memadai (Pencegahan dan Penanggulangan Plagiat di Perguruan Tinggi 2010).”

Sehingga perilaku plagiat sebagai salah satu bentuk penyalahgunaan informasi harus dihindari. Beberapa cara dalam penggunaan informasi ilmiah guna menghindar plagiat adalah dengan melakukan parafrase terhadap informasi yang akan kita gunakan. Selain itu kita juga perlu memadukan informasi yang kita peroleh dengan pengetahuan yang kita miliki. Kemudian pada tahap ini peserta juga diajarkarkan untuk menggunakan kutipan atau sitasi guna memberikan catatan atau pernyataan sumber informasi tesebut. Disamping itu peserta literasi juga melakukan instalasi perangkat lunak untuk membantu pembuatan sitasi dan pencatatan bibliografi yaitu Mendeley.

Pada tahap akhir dalam program kelas literasi ini dilakukan posttest untuk melihat hasil dan dampak program kelas literasi pada kemampuan literasi mahasiswa. Selain itu posttest digunakan untuk melihat sejauh mana tingkat efektivitas program ini diterapkan di kemudian hari. Dari hasil posttest diperoleh nilai rata-rata 67 pada tingkat pengetahuan dan kemampuan literasi informasi. Hal ini menunjukkan adanya perkembangan yang signifikan setelah dilaksanakannya kelas literasi.

Selain dari hasil posttest, diketahui perkembangan tingkat pengetahuan dan kemampuan literasi informasi juga bisa dilihat dari hasil karya tulis mahasiswa berupa makalah yang merupakan tugas perkuliahan. Makalah dari mahasiswa peserta kelas literasi menggunakan sumber-sumber atau referensi yang beragam dan merujuk pada sumber-sumber informasi ilmiah berupa artikel jurnal serta tulisan-tulisan ilmiah lainnya. Temuan ini berbeda jika dibandingkan dengan karya tulis beberapa mahasiswa yang tidak mengikuti kelas literasi yang hanya merujuk pada beberapa sumber buku yang relatif sedikit dan masih menggunakan sumber dari beberapa situs internet yang bersifat bebas dan tidak dapat dipastikan kevalidannya. 


\section{Kesimpulan}

Dari hasil pembahasan diatas menunjukkan bahwa sebelum dilaksanaaknnya kelas literasi informasi, tingkat pengetahuan dan ketrampilan literasi informasi mahasiswa UNU Yogyakarta masih cukup rendah. Hal tersebut dari dapat dilihat dari nilai hasil pretest yang hanya memiliki nilai rata-rata 23. Namun setelah dilaksanakan kelas literasi informasi, kemampuan literasi informasi mahasiswa mulai meningkat. Peningkatan terlihat dari nilai rata-rata posttest pada angka 67. Selain itu peningkatan kemampuan literasi mahasiswa pasca pelaksanaan kelas literasi juga terlihat dari kualitas sumber-sumber referensi dalam karya tulis mahasiswa peserta kelas literasi dimana sebelumnya haya merujuk pada beberapa sumber buku yang relatif sedikit dan masih menggunakan sumber dari beberapa situs internet yang bersifat bebas. Dari temuan-temuan tersebut dapat disimpulakan bahwa program kelas literasi informasi berperan secara signifikan dalam peningkatan kemampuan literasi bagi mahasiswa UNU Yogyakarta. Selain itu program kelas literasi juga dirasa lebih efektif dikarenakan diikuti oleh mahasiswa tahun pertama, sehingga menjadi suatu awal yang baik sebagai modal bagi seorang akademisi.

\section{Saran}

Dari penenelitian ini kami memberikan beberapa saran yaitu, pertama pihak perpustakaan UNU Yogyakarta disarankan untuk dapat melanjutkan program kelas literasi ini dikarenakan dinilai memberikan peran yang cukup signifikan bagi peningkatan kemampuan literasi informasi mahasiawa. Kedua, program kelas literasi ini masih perlu dilakukan pengembangan lebih lanjut, sehingga akan didapat model program kelas literasi yang berkesinambungan dan lebih sempurna. Ketiga, program kelas literasi semacam ini perlu dijadikan program prioritas bagi proses akademik mahasiswa yang komprehensif dan berkelanjutan, agar kemampuan literasi menjadi suatu kemampuan standar bagi mahasiswa yang akan melaksanakan tugas akhirnya. 


\section{DAFTAR PUSTAKA}

Eisenberg M. B. 2004. Information Literacy: Essential Skills For The Information Age. London: Libraries Unlimited.

Rubin, Richard E. 2004. Foundation of Library and Information Science 2nd Edition. New York: Nead Schuman Pulisher.

Permendiknas Nomor 17Tahun 2010 tentang Pencegahan dan Penanggulangan Plagiat di Perguruan Tinggi Pasal 1 ayat 1.

Prama, Husain Haikal. 2015. Class Library sebagai Program Literasi Informasi di Perpustakan SD Islam Al-Azhar 20 Cibubur. Skripsi. Jakarta: UIN Syrif Hidayatullah Jakarta.

\section{JURNAL}

Hasugian, Jonner. 2008. Urgensi Literasi Informasi dalam Kurikulum Berbasis Kompetensi di Perguruan Tinggi. Pustaha: Jurnal Studi Perpustakaan dan Informasi. Vol. 4, No. 2: 35.

Khadijah, Ute Lies Siti, Rejeki, Diah Sri, dkk. 2016. Literasi Informasi Motivasi Berwirausaha Ibu Rumah Tangga Kelurahan Nagasari Kabupaten Karawang Barat. JURNAL KAJIAN INFORMASI \& PERPUSTAKAAN. Vol.4/No.2: 151-152.

Purwono. 2008. Strategi Penelusuran Informasi Melalui Internet. Paper dipresentasikan dalam acara Seminar Himpunan mahasiswa Jurusan Ilmu Perpustakaan Fakultas Adab dan Humaniora Universitas Islam Negeri Jakarta. 10.

Zulaikha, Sri Rohyanti. 2008. Analisis The Big Six Model dalam Rangka Implementasi Information Literacy di Perpustakaan. FIHRIS. Volume III Nomor 2: 41.

Zulaikha, Sri Rohyanti, Suardiman, Siti Partini, dkk. 2015. Pengembangan Model Perpustakaan Madrasah dalam Penerapan Literasi Informasi untuk Mempersiapkan Belajar Sepanjang Hayat. Jurnal Pembangunan Pendidikan: Fondasi dan Aplikasi. Volume 3. No 2: 213. 


\section{WEB}

American Library Association. Presidential Committee on Information Literacy: Final Report. http://www.ala.org/ala/mgrps/divs/a crl/ publications/whitepapers/ presidential.cfm. diakses pada tanggal 13 Desember 2019. 